\title{
RAD21 wt Allele
}

National Cancer Institute

\section{Source}

National Cancer Institute. RAD21 wt Allele. NCI Thesaurus. Code C93086.

Human RAD21 wild-type allele is located in the vicinity of $8 q 24$ and is approximately $29 \mathrm{~kb}$ in length. This allele, which encodes double-strand-break repair protein rad21 homolog, plays a role in the modulation of chromosome cohesion, the mediation of DNA repair and the regulation of apoptosis. 